\title{
Rayleigh wave phase velocities and upper mantle structure in the Apennines*
}

\author{
M. Caplito (1) - I. Kxopofi $\left({ }^{2}\right)-$ \\ E. Mantovaxi $\left({ }^{3}\right)$ - St. Muelder $\left({ }^{4}\right)$ - G. F. Paxza $\left({ }^{5}\right)\left({ }^{*}\right)$
}

Received on Neptember 20 ith, 1976

Semary. - The dispersion of the phase volocities of the surface Rayleigh waves on the path between the station pair Torino-I, Aquila in the Apennines has been observed with long period seismic stations for twin cantliquakes.

The inversion was provided by the "IIedgehog" program of non-linear inversion analysis.

The interpretation supports the notion that in the Apennines low-veloaity material in the mantle is found within a few $\mathrm{km}$ of the Molo and may lie immediately below the Inoho; however the altemative model of a highvelocity lid and very low-velocity channel cannot be completely rejected.

Rrassunto. - Mediante stazioni sismiche a lungo periodo, ¿̀ stata studiata, per terremoti gemelli, la dispersione della velocita di fase delle onde superficiali tipo Raçeigh. in un tragitto compreso fra le stazioni di Torino e lípuila, lungo gli Appennini.

L'inversione is stata fornita dal programma "II edgehog" per lanalisi d'inversione non-lineare.

(*) Publication Nr. 1570, Institute of Geophysies ind Planctary Plyysies, University of California - Los Angeles.

Vitteilung Nr. 141, Institut für Geophysik - ETII Zürich.

(1) Istituto di Geofisiea, Roma - Eniversití di Bologna.

$\left({ }^{2}\right)$ Institute of Geophysies A Planetary Physies, Vniversity of California - Jos Angreles.

$\left({ }^{3}\right)$ Osservatorio Geofisieo - Vniversità di Siena.

(1) Institut für (ieophysik lidgenösische Technische IIochschule \%ürich.

(5) Istituto di Geodesia e Geofisica - Universiti di Bari, and Dipartimento di scienze della Terra, Iniversita deegli studi - Cosenza.

$\left.{ }^{* *}\right)$ Authors listed in alphabetical order. 
200 M. CAPUTO-L. KNOPOFF- E. MANTOVANI - ST. MUELLER - G. F. PANZA

L Zinterpretazione suggerises che, in corrispondenza degli Appennini, materiale a bassa velocita si frovi nel mantello in una zona compresa fra pochi km sopra lis Moho e immediatamente sotto. non eseludento completamente, tuttavia, il modello alternativo di una coltre ad alta velocita da un canale a velocita molto bassa.

\section{INTRODUCTION}

The development of techniques for inversion of Rayleigh wave dispersion data has been a significant factor in delineating lateral inhomogeneities in the earth's crust and upper mantle. The pioneering activities in the measmement of dispersion were carried out by Brune and Dorman (1963) (7) for the Camadian Shield and by Knopoff et al. (1966) (1-1) for the Alps. Since that time, a considerable quantity of data has been amassed regading Rayleigh wave dispersion in many parts of the world.

However, the systematic interpretation of these observations was not possible until the geophysical inverse problem was developed into a practical and efficient tool. Inversion studies have been cantried ont on two fronts. First, the linear inverse problem has been studied from the point of view of eigenvalue-eigenfunction analysis of non-squale matrices for underdetermined systems of equations; these matrices characterize the problems of determining real earth structure from insufficient amounts of data (Backus and Gilbert, 1968, (1) 1970; (²) Jackison, $1972)\left({ }^{11}\right)$. Second, the non-linear inverse problem has been attacked by a systematic attempt to constaruet the space of parameterized models, consistent, with the observations within certain error boumds (Biswas and Knopoli, 197t; (4) Knopolf and Schlue, 1972) (15).

The application of these techniques to the study of relatively stable parts of the earth has led to some important genemaliations regarding the structure of the upper mantle:

1. - Under all the ancient preCambrian shields of the world, no signilicant low-velocity channel exists (Knopoff, 1972). $\left({ }^{13}\right)$ These parts of the continents have a root which extends to great depths. The absence of a well-developed low-velocity chamnel implies temperatures well below the melting point of mantle rocks; this is associated with sub-normal surface heat How, and hence with geotherms which do not intersect the solichus.

2. - Under all the younger stable continental regions of the world, a well-rleveloped low-velocity channel exists starting at a depth 
of about $90 \mathrm{~km}$ (Knopoff, 1972 ) (13). The shear-wave velocity contrast: between lid and chamnel is about $0.3 \mathrm{~km} / \mathrm{sec}$. These values of shear velocity in the chamel imply temperatures above the solidus and hence partial melting of the mantle rocks in this region; this is associated with normal surface heat flow, and hence with geotherms which intersect the solidus.

3. - Under the Pacilic, a well-developed low-velocity chamnel exists, with a shear-wave velocity contrast between lid and chamnel of about $0.5 \mathrm{~km} / \mathrm{sec}$. The thickness of the lid increases with increasing lithospheric age (Leeds et al., 197t) $\left({ }^{17}\right)$, starting with zero thickness at the Rast Pacific Rise and increasing to about 100 to $110 \mathrm{~km}$ at a lithospheric age of $150 \mathrm{my}$ (Leeds, 1975) (16). The interface between lid and chamnel appears to be at the solidus for a wet peridotite.

Although the mantle unler the stable parts of the world aplear to have systematically similar properties, the less stable parts have been less thoroughly stulierl. Notable among these less stable aras are the monntainous regions of the world. Although some of the world's mountainous regions have been explored using surface waves, the mantle under these regions have not as yet shown any major tendency toward systematization. Among the individual areas studied, we can list regions associated with subduction zones (James, 1971) (12), rift zones (Biswas and Knopoff, 1974(4); Knopofi and Schlue, 1972(15): Seidl et al., 1970) (20) and folded belts (Knopofi, et al., 1966) (14).

It is reasonably easy to see why mountainous regions are difficult to understand. They are the surface expression of major tectonic activity either in the present or in the past. Thus, in some complex way, they reflect extraordinary stress conditions, such as those foumb at plate margins. The several types of tectonic interaction may have correspondingly different types of mantle structure beseath their respective surface expressions. By studying the upper mantle structure mulerneath mountainous regions, we have the possibility of learning something about the depth range of interaction stresses at plate bomdaries and possibly something about the thermal regime in these areas.

One of the most accessible areas for this kind of study is the Italian peninsula. Italy may be an artifact of an earlier episonle of tectonic activity in which the Alps were formed, and in which the Western Basin of the Mediteranean was opened up, perhaps contemporaneously with the rotation of the Iberian Peninsula. In any case, the mpler mantle under the Western Basin seems to have a more or less nomal oceanic 
structure at clepth, with a possible transition structure at the top of the lid (Berry and Knopoff, 1967) $\left(^{3}\right)$; the $\mathrm{Nlps}$ have an extraordinarily well-rleveloped channel at relatively shallow depths, with the lowest channel $S$-wave velocity reported for any continental region, except for the East African Rift (Knopolf et al., 1966) (14); the islands of Sardinia and Corsica have no significant seismicity and may have normal upper mantle structure for young stable continental regions (Berry and Knopoff, 1967) $\left(^{3}\right)$. There is volcanism in the southern part of Italy, earthquakes abound in the entire peninsula and especially to the south of the Po Valley, there is geothermal activity over the entire peninsula, and deep-focus earthquakes and high heat flows are found in the Tyrrhenian Sea. Evidently Italy is surrounderl by regions with widely different tectonic settings and with widely different crust and mantle structures; these structures are changing rapiolly with lateral distance. For these reasons, it is of especial interest to try to determine the upper mantle structure beneath the Italian Peninsula, and perhaps to determine the tectonic processes that could give rise to this structure. In this paper, we report on a first step in this program.

\section{I):T}

In a cooperative program originated by the Institut fü Geoplyssik, Swiss Ferleral Institute of Technology, /urich, the Institute of Geophysies, University of California, Los Angeles and the Istituto di Geofisica, University of Bologna, a network of long-perion seismic stations has been installed over the entire length of the Italian Peninsula. Each station is equipped with 15-100 Sprengnether (WWSSS equivalent) seismographs. All of the stations have a reptical-component seismograph and some are equipped with three components. The stations are:

$$
\begin{array}{ll}
\text { OLB } & \text { Olbia } \\
\text { TXO } & \text { Torino } \\
\text { BIZ } & \text { Bolzano } \\
\text { BOI } & \text { Bologma } \\
\text { BAR } & \text { Bari } \\
\text { NPI } & \text { Napoli } \\
\text { PIAM } & \text { Palermo } \\
\text { CAG } & \text { Cagliari } \\
\text { GRO Grosseto } \\
\text { ROM } & \text { Roma }
\end{array}
$$


These stations are used to supplement the existing WTSSN stations

$$
\begin{aligned}
& \text { AQU L Aquila } \\
& \text { TRI Trieste }
\end{aligned}
$$

to form a relatively dense network. The first of these stations was installed in 1970; all have been operating for varying lengths of time since their installation.

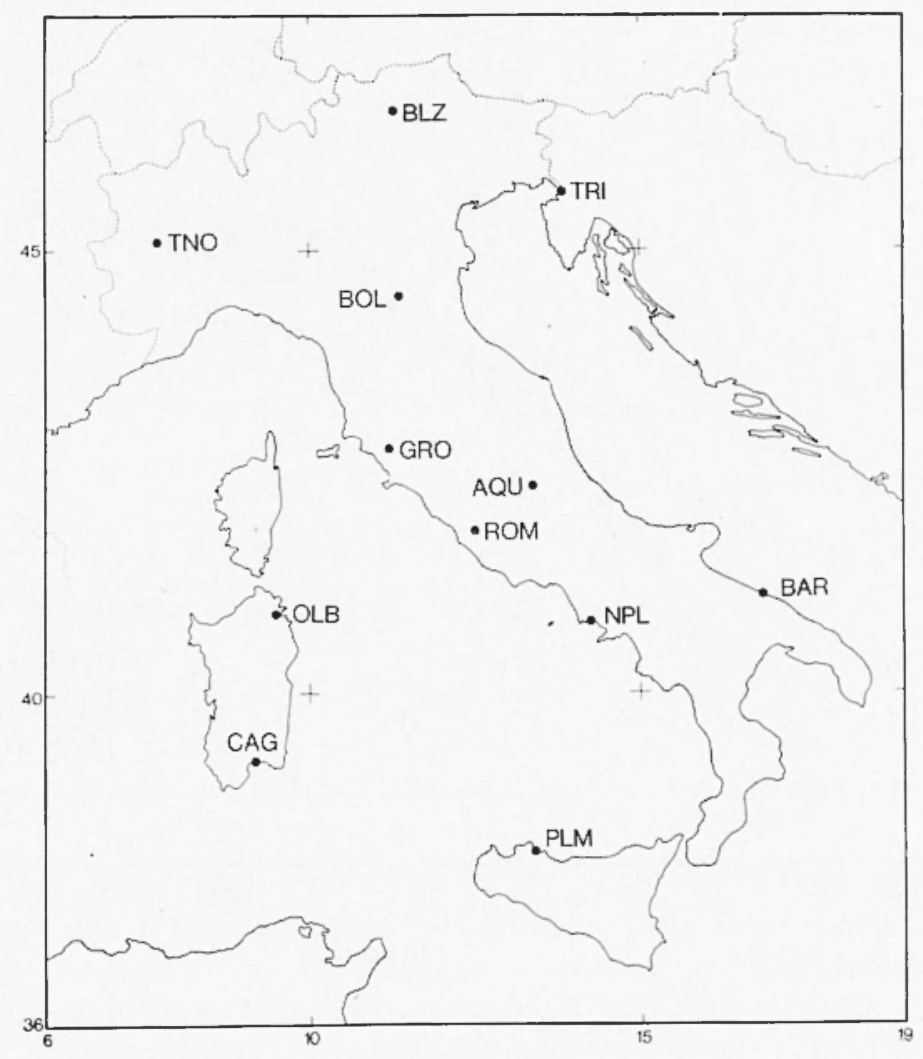

Fig. 1 - Map of Italian Peninsula showing network of long-period seismographs.

In this paper, we report on the result of processing seismograms taken for twin earthquakes in the North Atlantic at $54.30 \mathrm{~N}, 35.10 \mathrm{~W}$ :

Event 1: 3 April 1972 18:52:59.3 $\mathrm{M}_{s}=5.7$

Event 2: 3 April 1972 20:36:22.2 $\mathrm{MI}_{s}=5.5$ 
The two events give different phase velocities beanse of the different signal-to-noise ratios and the varying character of the noise; errors in the analysis due to regional refactions of the surface waves outside the station pair cannot be assessed in this analysis; however, studies of surface waves in the Alps emanating from events in this part of the Atlantic showed few if any refraction effects (Knopoff, et al., 1966 $\left({ }^{14}\right)$.

The records for the station pair TSO and $A Q \mathrm{U}$ were analyzed by time-windowing and frequency-filtering techniques described by

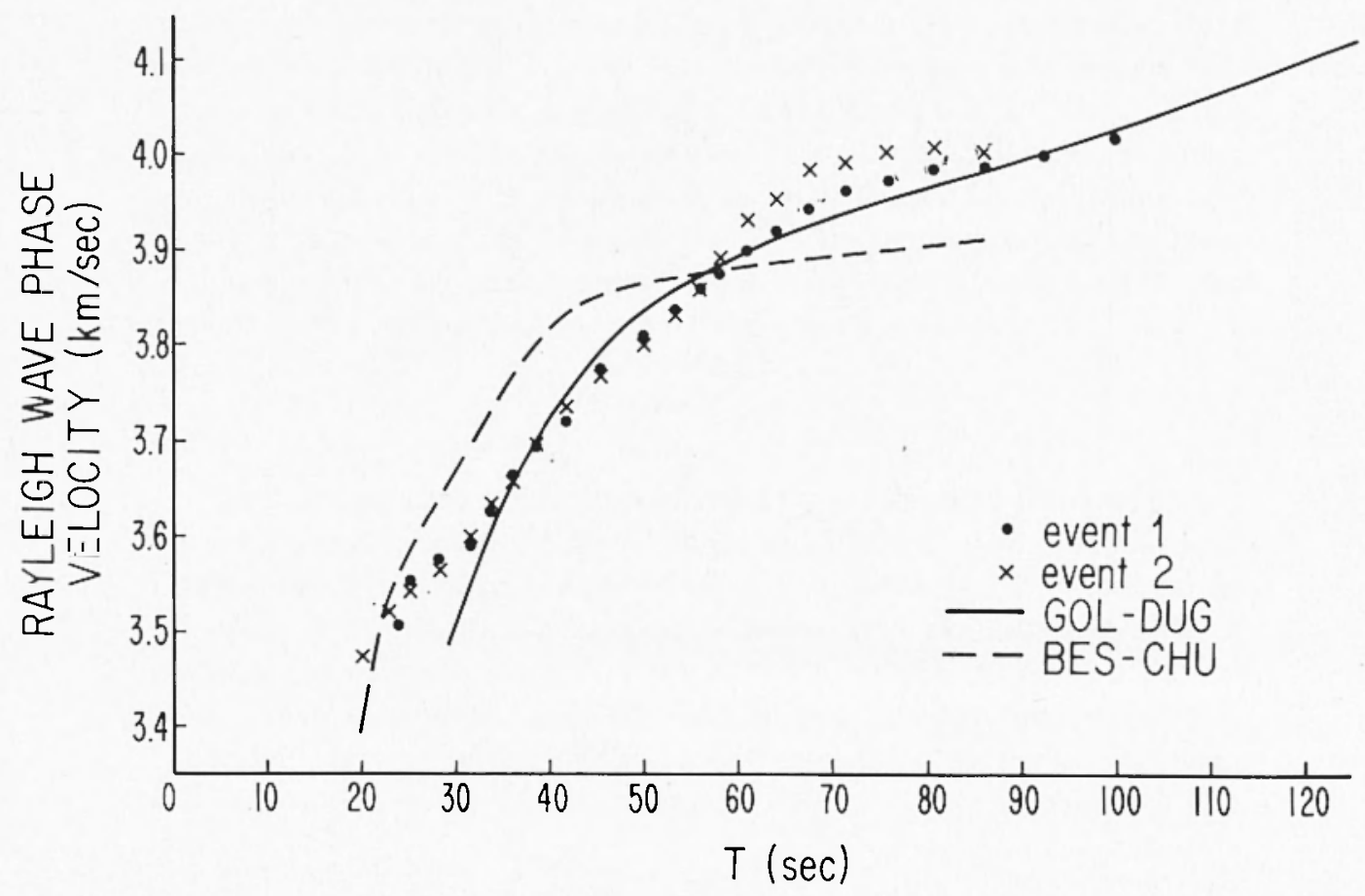

Tigr. 2 - Mrasured Ravleigh wave phase velocities for events 1 and 2 for path 'TO-AQL. Comparison ean be make with measuced phase velocities

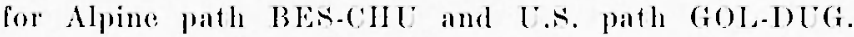

Pilant and Knopofl (1964) (19) and Knopoff et al. (1966)(1.4) and refined by Biswas and Knopoft $(1974)\left({ }^{4}\right)$, Panza (1976) (18). The nominal great circle paths to the stations from these earthquakes are within $3^{\circ}$ of the station pair line. The results of the phase velocity analyses are given in Table 1 for selected ralues of the multiples of the folding 
TABLE I

Pall 'TNO-AQL: - Phase velocities (km'sere)

\begin{tabular}{|c|c|c|c|c|}
\hline 'T. (sec) & $e_{1}$ & $c$ & 0 & $c_{f}$ \\
\hline $\begin{array}{r}100.0 \\
92.6 \\
86.2 \\
80.7 \\
75.8 \\
71.4 \\
67.6 \\
64.1 \\
61.0 \\
58.1 \\
55.6 \\
53.2 \\
50.0 \\
45.5 \\
41.7 \\
38.5 \\
35.7 \\
33.3 \\
31.3 \\
27.8 \\
25.0 \\
23.8 \\
22.7 \\
20.8 \\
20.0\end{array}$ & $\begin{array}{l}4.012 \\
3.997 \\
3.983 \\
3.981 \\
3.969 \\
3.958 \\
3.936 \\
3.916 \\
3.896 \\
3.873 \\
3.859 \\
3.835 \\
3.809 \\
3.771 \\
3.719 \\
3.693 \\
3.664 \\
3.624 \\
3.591 \\
3.576 \\
3.555 \\
3.506\end{array}$ & $\begin{array}{l}4.001 \\
4.005 \\
4.0000 \\
3.991 \\
3.983 \\
3.952 \\
3.931 \\
3.889 \\
3.858 \\
3.830 \\
3.799 \\
3.767 \\
3.735 \\
3.696 \\
3.657 \\
3.632 \\
3.598 \\
3.565 \\
3.539 \\
3.521 \\
3.472 \\
3.474\end{array}$ & $\begin{array}{l}3.594 \\
3.547 \\
3.521\end{array}$ & $\begin{array}{l}3.875 \\
3.774 \\
3.702\end{array}$ \\
\hline
\end{tabular}

frequency; the values are listed as $e^{1}$ and $e^{2}$ for the two earthquakes. Although the values of $e$ are listed to three decimals, this is merely a literal interpretation of the computer output; the results are accurate only to several humdredths of a $\mathrm{km} / \mathrm{sec}$. The maximum phase velocity differences between $e^{1}$ and e- are $0.04 \mathrm{~km} / \mathrm{sec}$, which may easily arise due to the small station pair distance interval.

\section{INERSION}

For the purposes of inversion, a data set " was created which is a simple average of the values where arailable. These spherical-eath Rayleigh-ware phase-relocity values were reduced by the Bolt-Dorman 
206 M. CAPUTO - L. KNOPOEF - E. MANTOVANI - ST. MUEL.ER - G. F. PAXZA

TABLE 11

Cross section used in the inversion

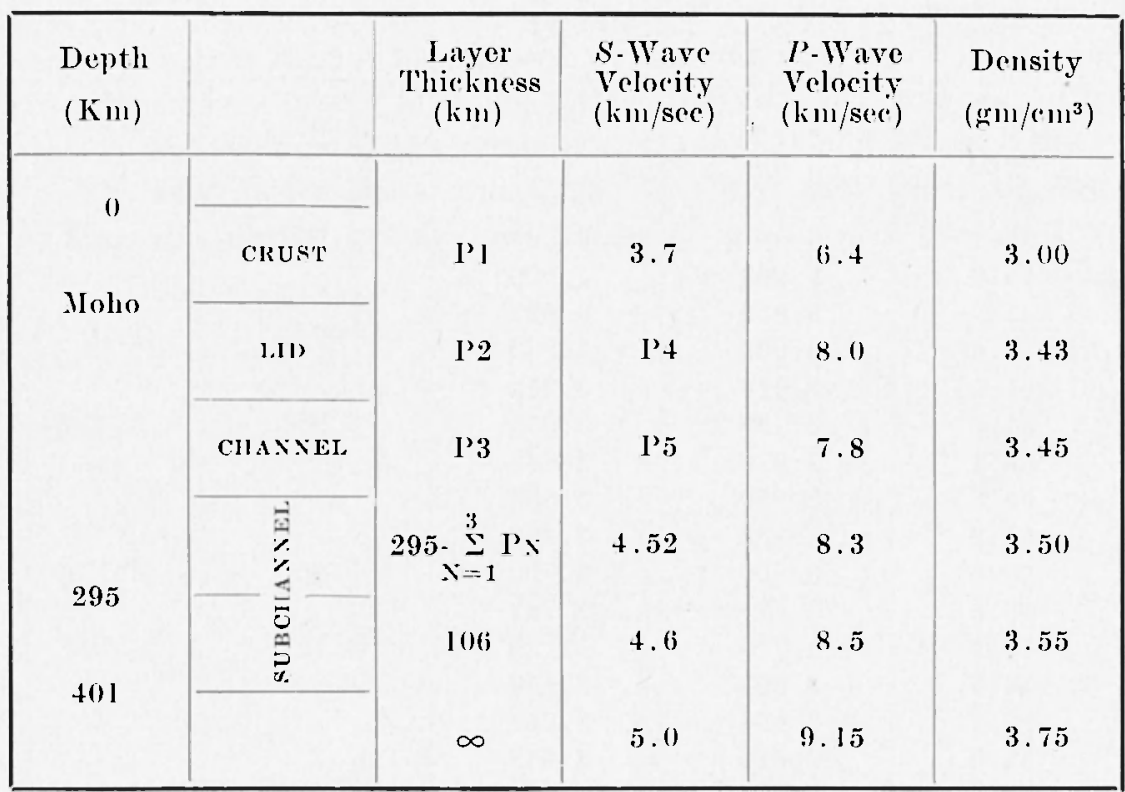

conficlence limits $\quad \sigma=0.03 \mathrm{~km} / \mathrm{sec}$

single point rejection if $|\Delta c|>0.05 \mathrm{~km} / \mathrm{sec}$

\begin{tabular}{|c|c|c|}
\hline parameter & l'ange & starting value \\
\hline I'l & $35(10) 65$ & 55 \\
I'2 & $20(10) 60$ & 40 \\
I'3 & $10(20) 150$ & 50 \\
I'4 & $4.21(0.1) 4.61$ & 4.31 \\
I'5 & $4.13(0.1) 4.53$ & 4.23 \\
\hline
\end{tabular}

provided by the Hedgehog program of non-linear inversion analysis. The cross-section used in the inversion is listed in Table II. Onr structure consists simply of five layers overlying a half-space, the latter beginming at a fixed depth of $401 \mathrm{~km}$. The crust has no velocity gradient associated with it. The subchammel begins where the channel terminates, but in any case it begins at a depth of less than $295 \mathrm{~km}$. 
The subchamel is divided into two regions with a small velocity difierence between them; the lower portion has a fixed thickness of $106 \mathrm{~km}$. The $P$-wave velocities and densities of the layers are fixed; numerical experimentation has shown that the values of these two parameters can cliffer from those used by substantial amounts, e.g., $0.5 \mathrm{~km} / \mathrm{sec}^{-}$ for $P$-wave velocity and $0.3 \mathrm{gm} / \mathrm{cm}^{3}$ for density, without significantly altering the phase velocities in this period range; this is another way of stating that fundamental mode Rayleigh wave phase velocities in this period range depend almost completely on the shear wave structure of the upper mantle.

There are five parameters in the Helgehog search, namely the crustal, lid and chamnel thicknesses and the lid and chammel s-wave velocities. These parameters are identilied as P1 to P5 in Table II. The seareh takes place ju the space of grid variables $x_{n}, n=1,2,3,4,5$, where

$\begin{array}{ll}\text { (clustal thickness) } & P 1=35<55+10 x_{1} \leqslant 65 \mathrm{~km} \\ \text { (licl thickness) } & P 2=20 \leqslant 40+10 x_{2} \leqslant 60 \mathrm{~km} \\ \text { (channel thickness) } & P 3=10 \leqslant 50+20 x_{3} \leqslant 150 \mathrm{~km} \\ \text { (lid velocity) } & P 4=4.21 \leqslant 4.31+0.1 x_{4} \leqslant 4.61 \mathrm{~km} / \mathrm{sec} \\ \text { (chammel velocity) } & P 5=4.13 \leqslant 4.23+0.1 x_{5} \leqslant 4.53 \mathrm{~km} / \mathrm{sec}\end{array}$

i.e., the allowable values of $x_{n}$ are

$$
\begin{aligned}
& x_{1}=-2,-1,0,1 \\
& x_{2}=-2,-1,0,1,2 \\
& x_{3}=-2,-1,0,1,2,3,4,5 \\
& x_{4}=\quad-1,0,1,2,3 \\
& x_{5}=\quad-1,0,1,2,3
\end{aligned}
$$

with the point $(0,0,0,0,0)$ as the starting point in the search. All solutions in the singly connected space $\left\{x_{n}\right\}$ are acceptable if the value of phase velocity predicted by the model differs from values listed as if in Table I by less than $0.05 \mathrm{~km} / \mathrm{sec}$ at each of the eight periorls and the root-mean-square of all eight differences is less than $0.03 \mathrm{~km} / \mathrm{sec}$. These astimates of error are based on past experience in processing sojsmograms of the quality of those obtained for these two events, the spacing between the stations and the similarity of the results for the two events.

The result of the Hedgehog inversion is presented in Table III; values of $\left\{x_{n}\right\}$ are listed as well as the values of the rms deviation between the model curve and the observations over the eight selected 
208 M. CAPUTO - KNOPOFF - E. MANTOYAXI - ST. WUELLEF - G.F.PAXZA

TABLE HI

Successful Solutions

\begin{tabular}{|c|c|c|c|c|c|c|c|c|c|c|c|c|c|}
\hline \multicolumn{3}{|c|}{$\begin{array}{l}\text { Solution } \\
\text { Number }\end{array}$} & \multicolumn{3}{|c|}{$x_{n}$} & \multirow[t]{2}{*}{$\sigma$} & \multicolumn{2}{|c|}{$\begin{array}{l}\text { Solution } \\
\text { Nomber }\end{array}$} & \multicolumn{3}{|c|}{$x_{n}$} & \multirow{2}{*}{\multicolumn{2}{|c|}{$\begin{array}{c}\sigma \\
.027\end{array}$}} \\
\hline 1 & 0 & 0 & 0 & 0 & () & & 40) & 0 & -1 & 3 & I & & \\
\hline 2 & 0 & 1 & 0 & 0 & () & .029 & +1 & 0 & 1 & 3 & I & I & . \\
\hline 3 & 0 & 0 & 1 & 1 & () & .026 & +2 & 0 & 0 & 3 & () & 1 & .027 \\
\hline 4 & 0 & 0) & 0 & I & -1 & .027 & 43 & 0 & -1 & 3 & 0 & 1 & .026 \\
\hline 5 & -1 & 0) & 0 & -1 & -1 & .029 & 44 & 0 & 1 & 3 & 0 & 1 & 7 \\
\hline 6 & 0 & -1 & 1 & 1 & 0 & .1026 & 45 & 0 & -2 & 3 & 1 & 1 & 027 \\
\hline 7 & 0 & I & 1 & I & 0 & .026 & 46 & 0 & -2 & 3 & 0 & 1 & .027 \\
\hline 8 & 0 & 1 & 1 & 0 & I & .028 & 47 & 0 & -2 & 3 & 2 & I & .030 \\
\hline 9 & 0 & $-I$ & 0 & I & -1 & 828 & 48 & 0 & 2 & 3 & 1 & 1 & .029 \\
\hline 10 & 0 & 1 & 0 & 1 & -1 & .026 & 49 & 0 & 2 & 3 & 0 & 1 & .028 \\
\hline 11 & 0 & 2 & 0 & () & 0 & .029 & 50 & 0 & -1 & 1 & 3 & -1 & .028 \\
\hline 12 & 0 & 2 & 0) & 1 & 0 & .030 & 51 & 0 & -2 & 2 & 3 & 0 & .020 \\
\hline 13 & 0) & 2 & 1 & 1 & 0 & .027 & 52 & 0 & -2 & 3 & 3 & 0) & 029 \\
\hline 14 & 0 & 2 & -1 & 0 & -1 & .029 & 53 & 0 & -2 & 3 & -1 & 1 & .030 \\
\hline 15 & 0 & 2 & 1 & 0 & I & .027 & 54 & 0 & 0 & 4 & 1 & I & .027 \\
\hline 16 & 0 & 2 & 0 & I & -1 & .027 & 55 & 0 & -1 & + & 1 & 1 & .026 \\
\hline 17 & 0 & 0 & 2 & I & () & 828 & 56 & 0 & 1 & + & I & I & .028 \\
\hline 18 & 0 & -1 & 2 & I & 0 & .028 & 57 & 0 & 0 & 4 & 0 & 1 & .027 \\
\hline 19 & 0 & 1 & 2 & I & 0) & 828 & 58 & 0 & -1 & 4 & () & 1 & .027 \\
\hline 20) & 0 & $-I$ & I & 2 & 0 & .028 & 59 & 0 & $I$ & 4 & 0 & 1 & .028 \\
\hline 21 & 0 & 0 & 2 & 2 & () & .030 & 60 & 0 & -2 & 4 & $\underline{2}$ & I & .028 \\
\hline 22 & 0 & 0 & 2 & 1 & I & .030 & (b) & 0 & -2 & + & 1 & 1 & .026 \\
\hline 23 & 0 & 0 & I & 2 & -1 & .029 & 62 & 0 & -2 & 4 & 0 & 1 & .026 \\
\hline 24 & 0 & -1 & 2 & $\underline{2}$ & 0 & .027 & 63 & 0 & 2 & + & 1 & 1 & .028 \\
\hline 25 & 0 & -1 & 2 & I & I & .030 & 64 & 0 & 2 & 4 & 0) & 1 & . 029 \\
\hline 26 & 0 & 1 & 2 & 1 & 1 & .030 & 65 & 0 & 2 & 4 & 0 & 2 & .028 \\
\hline 27 & 0 & 0 & 0 & 2 & -1 & .029 & $66 i$ & 0 & 0 & $\pi$ & I & 1 & .027 \\
\hline 28 & 0 & 0 & 2 & 0 & 1 & .027 & 67 & 0 & -1 & i) & I & 1 & .026 \\
\hline 29 & 0 & -1 & 0 & 2 & -1 & .027 & 68 & 0 & 1 & 5 & I & 1 & . 028 \\
\hline 30 & 0 & $\cdots 1$ & 2 & 0 & 1 & .027 & 69 & 0 & 0 & ij & 0 & 1 & .028 \\
\hline 31 & 0 & 1 & 2 & 0 & 1 & .027 & 70 & 0 & -1 & 5 & 0 & I & .027 \\
\hline 32 & 0 & -2 & 1 & I & 0 & .027 & 71 & 0 & I & $\tilde{5}$ & 0 & 1 & . \\
\hline 33 & 0 & -2 & 2 & 1 & 0 & .029 & 72 & 0 & 1 & 5 & 0 & 2 & .029 \\
\hline 34 & 0 & 2 & I & 2 & 0 & .026 & 73 & 0 & -2 & 5 & 1 & I & .025 \\
\hline 35 & 0 & -2 & 2 & 2 & 0 & .026 & 74 & 0 & -2 & 5 & 0 & 1 & .027 \\
\hline 36 & 0 & 2 & 2 & 1 & 0 & .028 & 75 & 0 & -2 & 5 & 2 & 1 & .027 \\
\hline 37 & 0 & 2 & 2 & 0 & 1 & .027 & 76 & 0 & 2 & 5 & 1 & I & 8. \\
\hline 38 & 0 & 0 & 3 & 1 & 1 & .028 & 77 & 0 & 2 & 5) & 0 & 1 & .030 \\
\hline 39 & 0 & $-I$ & 3 & 2 & 0 & .030 & 78 & 0 & 2 & 5 & () & 2 & . 027 \\
\hline
\end{tabular}


periods. Seventy-eight suecessful solutions were obtained. These solutions are plotted in a four-rlimensional representation of the space $\left\{x_{n}\right\}$ in Fig. 3.

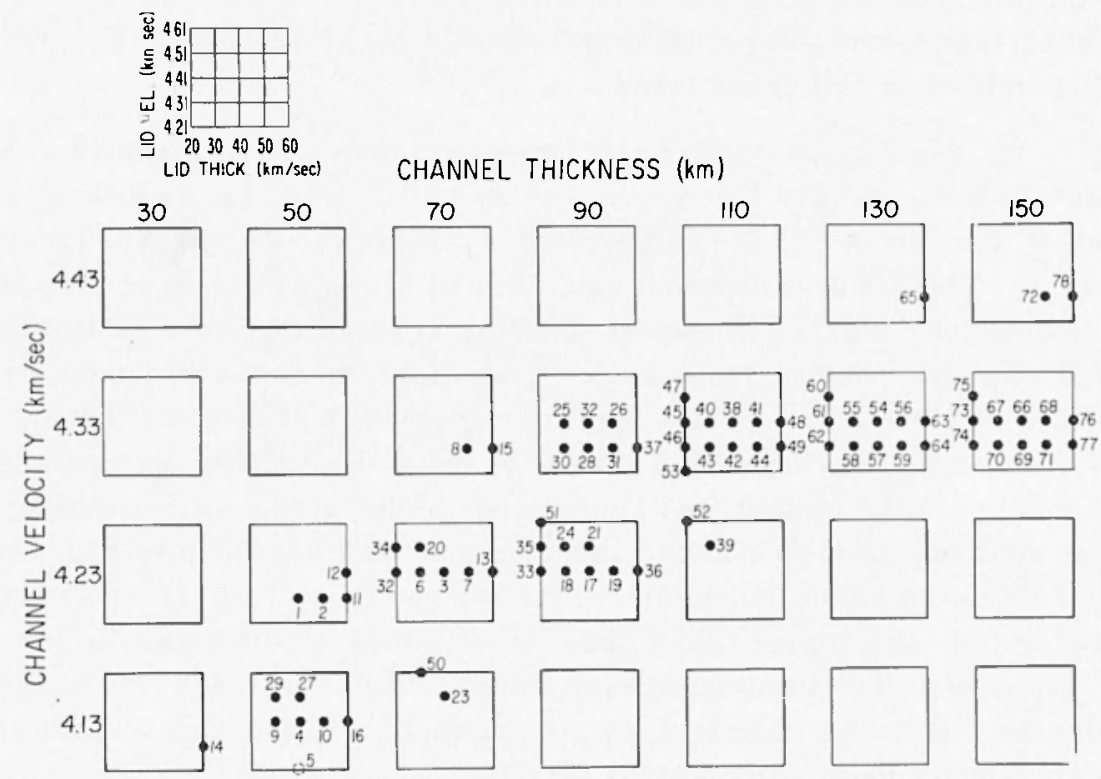

Fir. 3 - Four-dimensional space of acceptable solutions obtained from Ifedgehog inversion.

\section{INTERPRETATION}

1. All solutions except one (No. 5) have a crustal thickness of $5.5 \mathrm{~km}\left(x_{1}=0\right)$. All other crustal thicknesses are rejected. We believe that this severe restraint on $x_{1}$ is a consequence of the simplistic model of the erust that we have assumed. If we hath used a crust with a velocity gradient, especially with lower velocities at the top of the crust, we would have obtained a somewhat thinner crust. However, the value we have obtained is related in some measure to the vertical travel time of $S$-waves through the crust; since the crustal $S$-wave velocities camnot be altered by more than several tenths of a $\mathrm{km} / \mathrm{sec}$, the thickness will not be reduced by much more than about $10 \mathrm{~km}$ or so. (In Fig. 3, all solutions are plotted as solid circles, except Xo. ă, which has a different crustal thickness and is shown dotted). Be(ause of the apparent resolution of the crustal thickiness, we have used only the 
four remaining parameters in the diagram of acceptable solutions in Fig. 3.

The case of solution So. 5, with its decreased crustal thickness, requires much lower mantle velocities than the other solutions to keep) the vertical travel time in the upler mantle essentially invariant. We shall return to this point below.

2. For the crustal velocity cross-section we have assumed, we are unable to resolve the upermost $20 \mathrm{~km}$ or so of the mantle just below the Moho. This is illustrated by solutions $47,45,46,53$ in Fig. 3. These four acceptable morlels have the same values of coustal thickness (55 km), licl thickness $(20 \mathrm{~km})$, chanmel thickness $(110 \mathrm{~km}$ ) and chamnel velocity $(4.33 \mathrm{~km} / \mathrm{sec})$; the four models differ only by virtue of their lid velocities which range from 4.21 to $4.51 \mathrm{~km} / \mathrm{sec}$. Our conchusion is that a thin veneer of material of either high or low S-wave velocity located just beneath the Moho camnot be detected by our methods, and such a thin layer may or may not be present. As will be shown below, our preferred models are those with low-velocity material at the top of the mantle; in this case, a thin veneer of lowvelocity material is not significant since it blends with the rest of the mantle. Thus, we state that we are unable to tell if a thin veneer of high-velocity material is present or not.

3. Because of our inability to detect thin veneers, we focus our attention now on solutions with lid thickness $30 \mathrm{~km}$ or greater. In Fig. + we show the values of upper mantle velocities that have been found to be acceptable within the ariterion of fit by at least one structure. The circled entries give the number of solutions with these values of velocity. The fact that there are more solutions in one part of model space than in another is not persuasive. If the data are valid, the "real earth" can lie anywhere within the triangular region of Fig. 4, including the nupopular parts of this region.

A number of models have lid velocities of $4.31 \mathrm{or}+.41 \mathrm{~km} / \mathrm{sec}$; these values are unusually low for normal stable continental regions (Biswas and Knopoff, 1974(4); Knopoff, 197:2) (13). The low upper mantle velocities represented by the cases of $\beta_{I, I D}=4.31 \mathrm{or}+.41 \mathrm{~km} / \mathrm{sec}$ extend to depths which we anmot determine alequately with these data; we can accommolate positive and negative gradients of velocity as well as solutions with substantially no gradient, but in any case all these models have unusually low s-wave veloeities immediately below the Noho. 
Structures with s-wave velocities of the order of $4.3 \mathrm{~km} / \mathrm{sec} \mathrm{im}$ merliately below the Ioho have been obtained in inversion of phase velocities measured across the Colorado Plateau (Biswas and Knopofi, 1974) (1). The phase velocity for a two-station profile from Golden, Colorarlo to Dugway, Utah is reproduced in Fig. 2 for comparison.

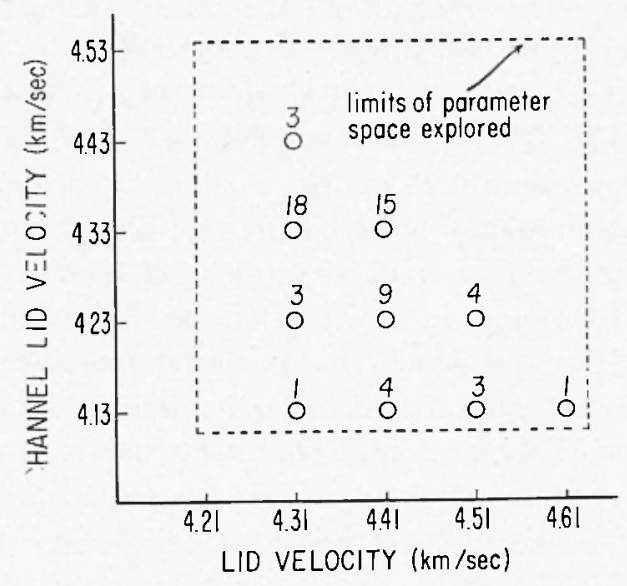

Pig. 4 - Two-dimensional shear-wave velo(rity spatere of acceptable solutions obtained from Hedgehog invorsion with lid thickness greater than or equal to $30 \mathrm{~km}$.

Except at the shortest periods, the phase velocities for TNO-AQU and GOL-DUG are remarkably similar. Thus, it is reasonable that the inversions for these two regions give similar results; the differences at short periods can be attributed to differences in crustal structure.

The solutions with lid velocity $4.51 \mathrm{~km} / \mathrm{sec}$ (Nos. 20, 24, 21, 39, $29,27,23$ ) or $4.61 \mathrm{~km} / \mathrm{sec}$ (No. 50) present a different kind of picture. In these cases, we have a lid of thickness up to $40 \mathrm{~km}$ below the Noho overlying a chammel of velocity from 4.13 to $4.23 \mathrm{~km} / \mathrm{sec}$. (We dirl not seek solutions with chamnel velocities lower than $4.13 \mathrm{~km} / \mathrm{sec}$.) In these cases, we have a relatively high velocity lirl overlying a chammel with remarkably low s-wave velocities. Chamel velocities this low have been observed in the oceans (Berry and Knopolf, 1967 (3); Leeds et al., 1974) (17) and in the Alps (Knopoff et al., 1966) (14). In the latter case, upper mantle models SPLA-(C,N) have crustal thicknesses of 40 or $50 \mathrm{~km}$, lids extending to depths of about $80 \mathrm{~km}$, lid relocities 
of $4.5 \mathrm{~km} / \mathrm{sec}$ or so, and chammel velocities of $4.15 \mathrm{~km} / \mathrm{sec}$ or so; these models are very similar to model 29 in Fig. 3. One important difference between the Alpine morlels and this subset of Apennines morlels is the differing thickness of low-velocity channel; we believe that we cannot resolve the bottom of the chamel with either set of data in view of the limited period range.

In Fig. ", we have also plotted the phase velocity for an Alpine profile extending from Besançon to Chur (event 6 October, 1960) reported by Knopoff et al. (1966) (1-4) which led to the Alpine morlels under comparison. The phase velocities for BES-CHU clifter from TNO-AQU by more than $0.05 \mathrm{~km} / \mathrm{sec}$ at about $40 \mathrm{sec}$ and perhaps also at 80 sec. The discrepancy between the two phase velocities at 40 sec illustrates the neel for a good crustal structure: we attribute this discrepancy to differences in crustal structure; certainly our morlel of a uniform crust for the Apennines is too simple. The difference in phase velocities at 80 sec, if real, must be attributed to differences in channel thickness, with the Alpine channel extending to greater depths.

4. How can we resolve the differences between the two groups of molels, namely, those with relatively low upper mantle velocities $\left(T_{s} \sim 4.3 \mathrm{~km} / \mathrm{sec}\right)$ starting at the Moho and extending downwar (the Coloralo Platean model) and the model with a thin lid of high velocities overlying a channel with exceptionally low velocities $\left(V_{\mathrm{s}} \sim 4.15\right.$ $\mathrm{km} / \mathrm{sec}$ ) (the Alpine molel)? In our view, the resolution will come only when more arlequate information about the crustal structure can be obtained. Caloi (1955), (8) using earthquake travel-times, has indicated that the Appemines in this region have a crustal thickness of about $45 \mathrm{~km}$. While this result is close to our value and may be correct, the paucity of data used in the study indicates that one should place greater emplasis on results obtained by refraction methods. Much to the south of the regions under consideration here, Colombi et al. (1973) (9) have foumd a crustal thickness of the order of 40 to $45 \mathrm{~km}$ under the Apenmines by refraction methorls. Based on sketchy information, Giese and Morelli (1973) (10) have attributed a crustal thickness to this region of 25 to $30 \mathrm{~km}$, a figure in marked contrast to onr value. Giese and Morelli also indicate that the preferred $P n$ velocity in this region is about $7.2 \mathrm{~km} / \mathrm{sec}$ These values inclicate the presence of extraordinarily low-velocity material just below the Moho, since a decrease in crustal thickness, as has alrealy been noted, accompanies a decrease in mantlo lid velocity. We believe that our value of crustal thickness 
may be a consequence of our oversimplified crustal model. This would then indicate a preference for our models of colorado Plateau type over the Alpine type.

Some support for this point of view should be found in greothermal evidence. If the mantle-lid s-wave velocities are low, starting from the Moho and extending downward, high surface heat flow should be observed. There is certainly geothermal activity in this area; a heat flow measurement at Larderello by Boldiszar (1963) (5) is 6 to 14 HFU. Larderello is hardly a typical location, but the presence of significant hot spring activity is important information that cannot be ignored.

\section{Coxchesions}

Rayleigh wave phase-velocity observations over the path TNO$\mathrm{AQU}$ indicate that there is a significant amount of low-velocity material in the mantle under the Apennines. The indications of low I'wave velocities at shallow depth, plus hot spring activity, when coupled with the inversion of our surface-wave observations, support the notion that low-velocity material in the mantle is foumd within a few $\mathrm{km}$ of the Moho and may lie immediately below the Moho; we camnot completely reject an alternative model, namely, that there is a high-velocity lid of thickness 30 to $40 \mathrm{~km}$ overlying a very low-velocity chamnel with $S$-wave velocities in the chamnel of about 4.1 to $4.2 \mathrm{~km} / \mathrm{sec}$.

Unfortunately, our observations are for earthquakes lying on only one side of the station pair TXO-AQU. A recersed profile, in which we observe dispersion for surface waves arring at the same stations from the south, is much to be hoped for since this would test the reality of attributing our observations to the structure between the two stations.

\section{ACKXOWLADGMETS}

The authors wish to acklnowledge the assistance of M. Gasperini (Bologna), W. Mitronovas (Zurich), J. Schlue (Los Angeles) and D. Seidl (Karlsubihe) for installation and maintenance of the long-period network. This work was supported by grants from the Consiglio Nazionale delle Ricerche, the Dentsche Forschungsgemeinschaft and N.A.T.(). 


\section{REFLRENCES}

(1) Backus, (4. and F. (inberT, 1968. - The resolving power of gross earlh data, "Geophys. J. Roy. Astron. Soc.", 16. pp. 169-205.

(2) Backus, (a. and F. Ginsirt, 1970. - Eniqueness in the incersion of inaccurate gross earlh data. "Phil. Trans. R. Soc. Lont.", 266 A, pp. $123-192$.

(3) BenRr, .1. J., and L. KNoporr, 1967. - Structure of the upper mantle under the Western .lediterranean Basin, "J. Goophys. Res.", 72. pp. 3613-3626.

(4) Biswas, X. X., and L. Kxopory, 1974. - Structure of the "lper mantle underthe Cuited states fromt he dispersion of Rayleigh wares. "Goophys. J. Roy. Astron. Soc.", 36. pp. 515-539.

(5) Botinzsak, 'T., 1963. - Terrestrial heat flow in the natural stream field at Larderello. "(icofis. Pura Appl.", 56, pp. $115-122$.

$\left.{ }^{6}\right)$ BoLT, B. A., and J. Dormax, 1961 . - Phase and yroup relocities of Rayleigh wares in a spherical, gravitaling earlh, "J. Geophys. Res.", pp. 66, 2965-2981.

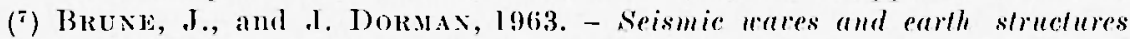
in the Canadian shield, "Bull. Seismol. Soc. Amor.", 53, pp. $167-210$.

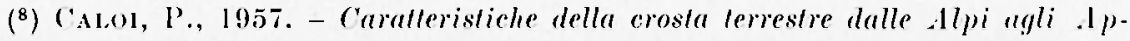
pennini, "Annali di Geofisica", 10. pp. 189-192.

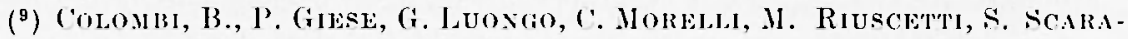

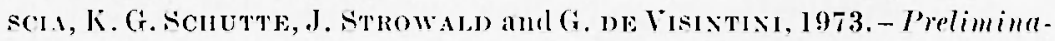
ry report on the seismic refraction profile Gargano-Salerno-Palermo-Pantellerie: (1971). "Boll. Geotis. Teor. ed Appl.", 15. pp. 225-254.

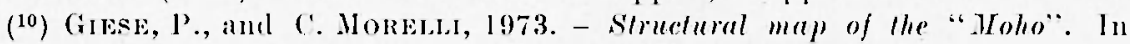
"Structural Morlel of thaly", Sheet south 2, CNR, Rome.

(11) JACksox, 1). D., 197. - Interpretation of inaceurate, insufficient and inronsistent dala. "Geophys. J. Roy. Astron. Soc.", 28, p1. 97-109.

(12) JAMEs, D. L., 1971. - Andean crustal and upper mantle structure. "J. Geoplyss. Res.", 76, pp. 3246-3271.

${ }^{13}$ ) Kisopor, L., 1972. - Obserwation and inrersion of surface wace dispersion. "Tertonophysies", 13, pp. 497-519.

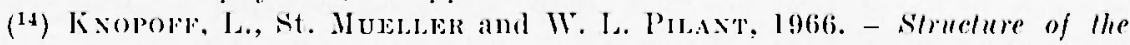
crust and upper manlle in the Alps from the phase velocity of Rayleigh waves. "Bull. soismol. Soc. Amer", 56, pp. 1009-104t.

(15) K.хоро\%, L., and J. W. Scinue, 1972. - Rayleigh wave phase velocilies for the path Adalis Ababa-Nairobi. "Tectonophysics", 15, p1). 157-163.

(16) Lends, A. R., 1975-Lilhospheric thickness in the Western Pacifie. "Plyys. Earth \& Planet. Interiors", 11, p. 61-64.

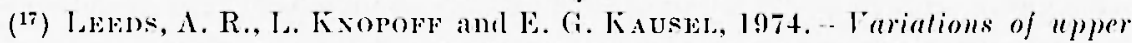
manlle structure under the Pacifie Ocean. "science", 186, p1. 139.141.

(18) Paxza, (4. F.. 1976. - Phase relocity determinalion of fundamental Lore and liayleigh mares. "Pure Appl. (ieophys.", 114, pp. 753-763.

(19) PILAxT, W. I.. and L. Kixopore, 1964. - Obserration of mulliple seismic crenls. "Bull. Seismol. Soe. Amer.", 54, pp. 19-39.

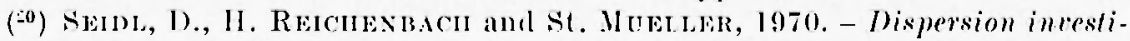
gations of Rayleigh wares in the Rhinequaben rift system. In "Graben Problems", pp. 203-206 J. ll. Illies and st. Muellor, eds. (sellweizerbatr Verlag, stuttgart, 1970). 